\title{
45. THE SEDIMENTARY HISTORY OF THE MEDITERRANEAN AREA DURING THE NEOGENE
}

\author{
W. D. Nesteroff, University of Paris VI, Paris, France.
}

\section{INTRODUCTION}

The alpine geologists know well that the AquitanianBurdigalian orogenic phase marks the beginning of recent sedimentation in the western Alps domain. A succession of transgressions and regressions affects the area, and the great number of land outcrops available and already thoroughly studied makes it possible to attempt a synthesis. In this paper, in the light of results of the Leg 13 drillings, we shall examine the evolution of sedimentation in the two marine areas, the western and eastern basins of the Mediterranean Sea, and their relations with the adjacent and peripheral basins of the western Alps.

However, for comparison, those sediments deposited under similar conditions should be considered. Our hypothesis is that during a given span in geological time, the "characteristic" sedimentation inside a given basin is the "pelagic", or "particle by particle" sedimentation. This rules out all other types of deposits: turbidites, coutourites, and the greater part of the littoral or shallow water sediments.

\section{THE MIDDLE MIOCENE}

With the Burdigalian Stage, the Miocene transgression begins to take place all over the Mediterranean and a major tectonic phase marks the western basin (Gignoux 1950, Durand Delga 1969). The part of the Miocene located between the Burdigalian and the evaporitic Messinian is known as the Vindobonian. It includes the Langhian, the Serravalean, and the Tortonian. In the course of our drilling, we reached Tortonian marls in the western basin and Langhian deposits in the eastern.

In the Alboran Sea, the Tortonian is composed of blue-grey hemipelagic marls. These contain high proportions of fine terrigenous clastics. The foraminiferal fauna is normal and indicates open sea conditions. The rates of sedimentation are low: $2 \mathrm{~cm} / 10^{3} \mathrm{y}$.

Tortonian deposits are numerous around the western Mediterranean as well as in southern or central Europe. They include many littoral sands, but when pelagic oozes are encountered, their facies is similar to that of the Tortonian of Site 121. Blue marls with Pleurotomes have been found in the Mistral drilling (Burolet et al., 1971) in the Rhône Basin, in Tortona (northern Appennines), in North Africa, and in Spain. Farther inland in the basins, shallower and more littoral deposits, such as Swiss molasses, replace the blue marls. Near the top, the Tortonian series becomes coarser, with development of the sandstones of the Lyonnais, before being covered by sheets of Pontian continental alluvials.

The deposits drilled in the eastern basin are more difficult to correlate. The older is the Langhian pelagic limestone of the Strabo Mountain (Site 129). It contains an open sea fauna. On the other hand, the overlying Serravalian and Tortonian blue gray marls comprise less diversified and poorer faunas (Site 129). In the Ionian Sea (Site 126), the Tortonian blue gray marls yield a poor, dwarfed planktonic fauna without benthic forams. The sediment is laminated (no bioturbation) and pyritic. The carbonate content is low $(5-13 \%)$, but consists wholly of calcite. The data suggest a restricted basin with reducing conditions at the bottom.

Hence, in the eastern basin, the Strabo Mountain (Site 129) Langhian marls are open sea deposits similar to those of the western basin. The yonger Tortonian and Serravalian marls (Sites 126 and 129) display a severely restricted facies. However, as the bulk of the biological fraction is comprised of nannoplankton, which is not affected by restricted conditions, the general appearance of the sediments remains the same-that of the blue marls.

During the Vindobonian, blue marls of a similar facies are widespread through the eastern Tethys and seem to be hemipelagic deposits. They represent the Tortonian in the wells drilled in the Ionian Islands (Bizon 1967). In central Europe, they form the schlier facies of the Vienna Basin. They occur in the east, in the Panonic Basin (Gignoux 1950), and elsewhere.

Therefore, for a long span of time, from the Burdigalian until the end of the Tortonian, the same sedimentary type, blue marls, is deposited inside the whole Mediterranean Basin. During that period, the sea covered an important part of central and eastern Europe, deeply penetrating inland gulfs such as the Rhône Basin. It is the Mésogée, a Vindobonian Tethys.

All these blue marls belong to the same lithology and include similar fauna. They are dark gray or dark blue. The calcium carbonate content is medium to low which indicates that the fine terrigenous clastics take a greater part in the sedimentation than does the biologic productivity. In some places, the sediments are laminated and the foraminiferal fauna is poor or dwarfed. These characteristics, together with the dark coloring, point to restricted basins with rather euxinic conditions on the bottom. A restricted oceanic circulation between the different basins may have been responsible.

The blue marls constitute a lithological unit or marine formation, in the geological sense of the term (Bell et al., 1961). Even if they differ slightly from one place to another, the blue marls are consistently different from the overlying Pliocene and Quaternary nanno or marl oozes, which are light colored and were deposited under oxidizing conditions.

We do not know the base of this formation, for our drillings did not reach the Aquitanian. The occurrence of a 
change in the facies of the deposits in the deep parts of the Mediterranean with the onset of the Burdigalian has yet to be investigated. On the other hand, the top of the formation is well known. On land, the end of the Tortonian is marked by a general regression that is the equivalent of the evaporitic regime encountered in the deeper basins. Thus, the top of the blue marl formation coincides with the top of the Tortonian.

\section{THE MESSINIAN}

The exact significance of the Messinian episode, as well as the exact correspondence between this stage and its non-marine equivalents, Pontian and Sarmatian, has long been a problem for European geologists, and a matter of great confusion.

During Leg 13, all the Messinian deposits drilled throughout the Mediterranean have proved to be evaporitic series. They are comprised of dolomitic marls interbedded with massive gypsum, anhydrite, and halite. Moreover, a series of characteristics have led us to conclude that these evaporites were deposited in shallow water. These are structures that have been observed on tidal flats in a number of warm seas, where evaporites still form a deposit today: algal reefs or stromatolites, nodular or chickenwire texture associated with laminated beds, benthic coastal or brackish faunas, isotopic analysis, etc., (see Nesteroff, Chapter 21; Friedman, Chapter 22.1; Lloyd and Hsu, Chapter 30.1; Fontes et al., Chapter 30.2).

At the same time, on land in circum-Mediterranean basins as well as in the Alps and southeastern Europe, Tortonian blue marls are very suddenly replaced either by evaporitic series or by lacustrine and continental deposits. This is why shreds of evaporitic series have been discovered in the circum-Mediterranean in such places as: North Africa, Spain, Italy (principally), the Appennines, and Sicily (Ogniben 1957). They have also been found in the Oriental Basin, in Greece, Cyprus, and Turkey, where the drillings have been cut through hundreds of meters of rock salt.

When one moves farther from the present Mediterranean Basin, geological sections either reveal the absence of the Messinian or its replacement by lacustrine or continental deposits. The Mistral drillings, in the Gulf of Lion, have thus shown that the Upper Miocene is missing (Burolet et al., 1971). Farther north, in the Rhône and Vienna basins, continental alluvia of Pontian age overlie the Tortonian marls. Finally, farther east, the extremely important area of the Panonic, Pontic, and Aral-Caspic basins has been converted into fresh water marshes-the Sarmatian lake-seas of Russian authors (Gignoux 1950, Zenkovich 1966).

Lastly, in every known bed the top of the evaporitic series is extremely distinct as well as synchronous. This top corresponds to the Pliocene transgression (Bourcart 1962; Nesteroff, Chapter 21).

In short, the Messinian stage is marked by a general regression in the Alpine domain and by the deposit of evaporites in areas that constitute, at present, the deepest parts of the Mediterranean Sea (Figure 3). Some fragments of these, however, are met again upon some of the margins of that sea-margins that we know to have been tectonically uplifted.
The explanation of all these geological events lies in the more or less complete isolation of the Mediterranean Sea during the Messinian. In the east, geological outcrops indicate that the seaway leading to the Indian Ocean was closed towards the end of the Tortonian (Zenkovich 1966). The Red Sea was still connected with the Mediterranean, but it was closed at its southern end and isolated, therefore, from the Indian Ocean (Heybroek 1965). In the west, the North-Betic and the South-Riff Straits were also closed, while the Gibraltar Straits did not yet exist. During the whole of the Messinian, however, the Mediterranean Sea was supplied, in an intermittent way, with salt water, as witnessed by the deposition of the evaporitic series. The probable source of this supply was the Atlantic Ocean, and its most likely geographical location, was either Gibraltar or the South-Riff area where Messinian marine outcrops are known.

Today, the hydraulic balance of the Mediterranean is negative, since evaporation is greater than the contributions of rivers. This negative balance is compensated for by water the Atlantic contributes through Gibraltar. The interruption, even partially, of the Atlantic contribution in the Messinian, caused the Mediterranean to dry up and turn into a desert with salt-brine basins in its deepest parts.

All this means that the abrupt replacement of Tortonian marine deposits by evaporites, or continental deposits, has one cause and one cause only, and that, moreover, it is synchronous inside the whole basin.

Consequently, the evaporites drilled in the deeper basins of the Mediterranean Sea, as well as the fragment shreds that are distributed all over the circum-Mediterranean, belong to one lithologic unit: The Messinian Mediterranean evaporite. This, in point of fact, constitutes a Formation, in the geological sense of the word, the lower and upper limits of which are very clearly defined petrographically.

These limits are also synchronous and coincide with those of the Messinian Stage. Hence, this lithologic unit is at the same time a chronostratigraphic and a biostratigraphic unit (Bell et al., 1961).

For the present, this formation is the largest evaporitic system we know. All the different basins put together are far more important than the Zechstein Group (700.000 $\mathrm{km}^{2}$ ) or the Dead Sea. The Tarim Basin, in the Sinkiang, could alone be compared to the Mediterranean.

Finally, the Messinian isolation is as much responsible for the regressions that have affected Europe (Rhône and Vienna Basins) as for the formation of lakes all over southern Russia. The continental Pontian deposiis and the Sarmatian lacustrine deposits are both, without doubt, stratigraphic equivalents of the Messinian.

\section{THE PLIOCENE AND THE QUATERNARY}

The deep Plio-Quaternary deposits surveyed in the course of the drillings of Leg 13 are composed of hemipelagic marl oozes that are light in color and often contain a high proportion of carbonate. Pelagic and benthic microfaunas are abundant and diversified. These marls are not laminated and bear evidence of the activity of benthic burrowing organisms. They consist of sediments deposited in an oxygenated medium inside basins where waters circulated freely. 


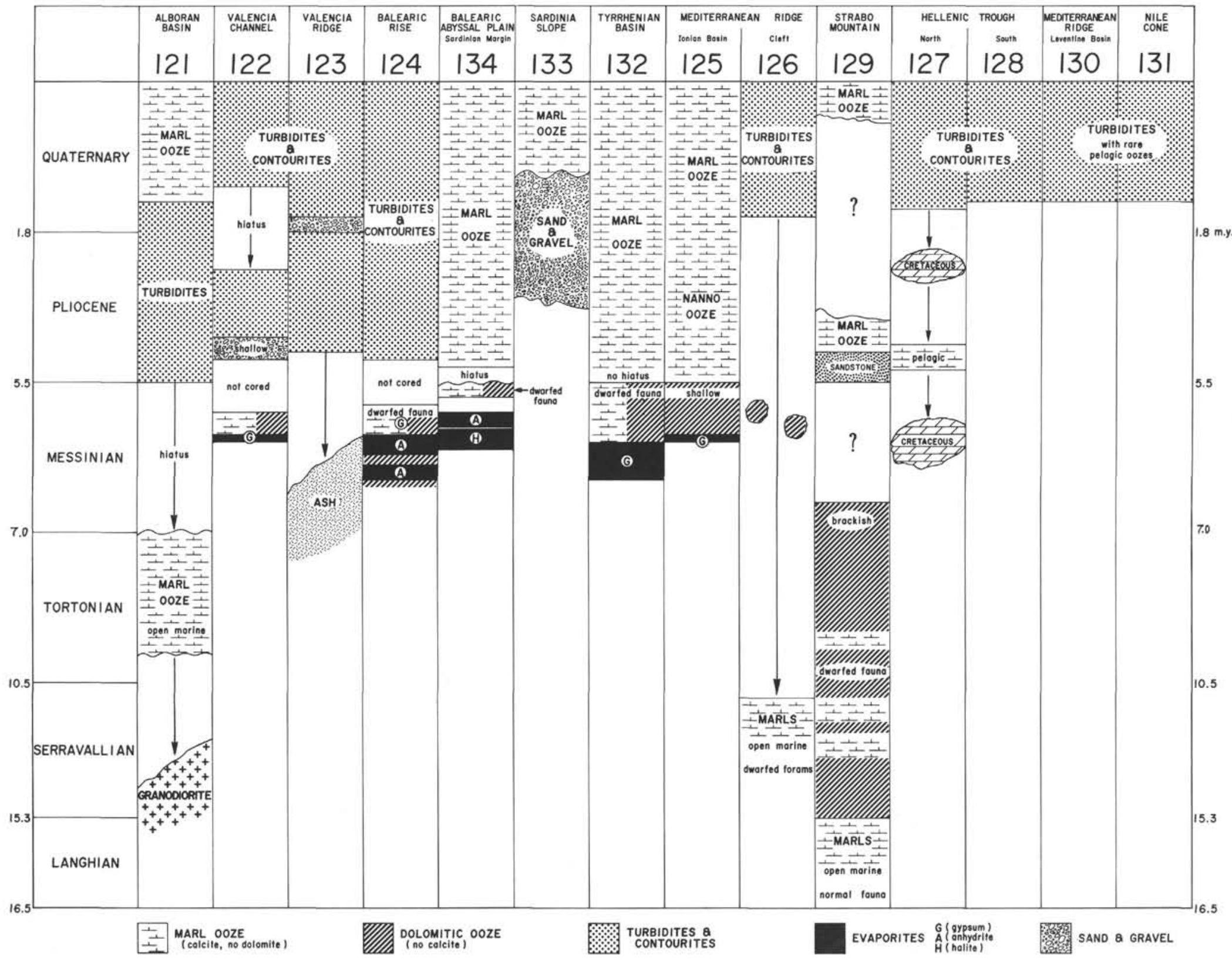

Figure 1. Stratigraphy and lithology of the Mediterranean sites. 


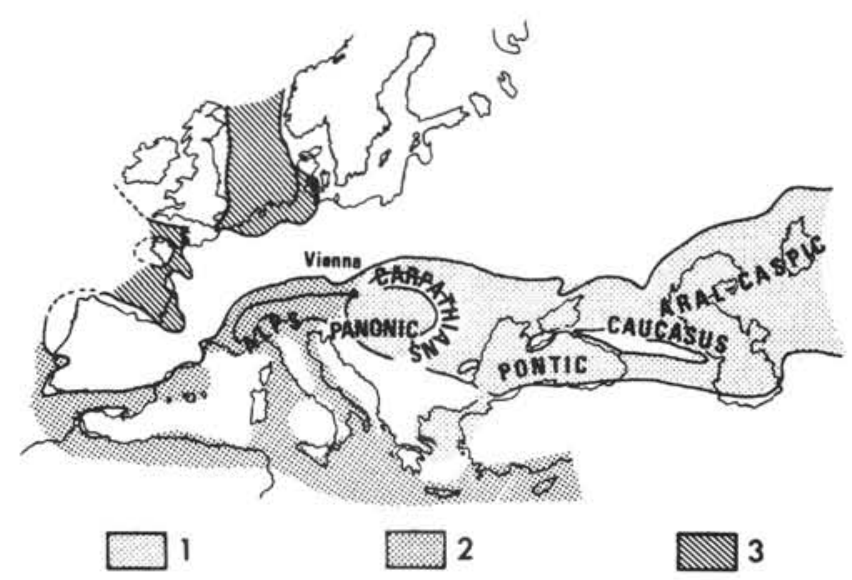

Figure 2. Marine (1 and 2) and lacustrian (3) basins in Europe at the end of the middle Miocene /Gignoux, 1950).

The geological studies devoted to the emerged Pliocene and Quaternary in the circum-Mediterranean (Gignoux $1913,1922)$, as well as the results of numerous oceanographic cruises, show that this petrographic type is associated with the Plio-Quaternary hemipelagic deposits located everywhere in the Mediterranean. Specifically, the light-colored marls of the Trubi facies, which constitute the base of the Pliocene in the Gessosso Solfifera Series of the Appennines and Sicily (Ogniben 1957), have clearly the same facies as the light-colored foraminiferal marl oozes encountered at the bottom of the Pliocene in our Sites 125, 132 , and 134.

The replacement of the Messinian or Pontian deposits by the Pliocene marl oozes is amazingly abrupt. All contacts drilled during Leg 13 are erosive and often indicate important hiatuses. This is equally true on land (Gignoux 1913, Bourcart 1962). These new deposits are, from the first layer, marine and hemipelagic.

We know that, with the Pliocene, a new tectonic phase started. The movements were mainly vertical and affected the entire periphery of the Mediterranean Sea, the margins of which were raised while the central basins subsided (Durand Delga 1959, Bourcart 1962, Glangeaud 1962, Zenkovich 1966). At the same time, a real communication established itself with the Atlantic.

These data corroborate flooding by the sea of a desiccated basin sunk below the general level of the oceans. The Pliocene transgression would thus seem to have a specific character in the Mediterranean Sea that would mark it off from the transgressions that have submerged the margins of the continents.

It is possible that the South-Riff area acted as a strait before being replaced, later on, by Gibraltar (Faure-Muret and Choubert, personal communication). The Atlantic waters rushed into the Mediterranean and circulated freely within it. The establishment of these new conditions resulted in a deposit of light-colored and oxygenated marl oozes.

Judging by the two complete pelagic sedimentary columns drilled (Site 132 Tyrrhenian Sea, Site 125 Ionian Sea), Plio-Quaternary sedimentation seems to have been continuous. However, seismic records reveal that there are angular discordances at the foot of some continental margins such as those of the Balearic Islands (Site 124). Actually, these margins are composed of contourites, that is to say, of bottom current deposits. The discordances therefore suggest that changes in the general current system in the Mediterranean have taken place.

Lastly, the appearance of sapropels in the Upper Pliocene and the Quaternary correspond to periods of stagnation at the bottom of the basins, or in other words, to new changes in the general hydraulic regime. It is interesting to note that sapropels have only been encountered in the eastern basin.

It can be said then, that the Plio-Quaternary marl oozes, which discordantly overlie the evaporites, constitute a new and unique lithologic unit-the unit of the light-colored marl oozes.

\section{CONCLUSIONS}

The Neogene outcrops scattered all around the Mediterranean Basin as well as in the Alpine domain belong to three large lithologic units. The limits between these units are clearly defined and, moreover, are synchronous. Each one is characterized by a specific petrography and presents indications as to the conditions of the original deposits. The oldest unit is represented by the Vindobonian blue marls. It is topped by the Messinian evaporite series. Finally, the third and last is that of the Plio-Quaternary light-colored marl oozes.

These deposits reflect, on the one hand, the evolution of communication between the Mésogée and the world ocean, and on the other, the depth conditions in the basins. Thus, in the Vindobonian, difficulties of communication, perhaps related to the shallowness of the basins, led to the deposit of blue marls. In the Messinian, the interruption of the communication brings about the accumulation of the evaporitic series. In the Pliocene, the deepening of the Mediterranean Sea, which added to the free circulation of the waters therein, was followed by the deposition of the light-colored and oxidizing marl oozes.

In the final analysis, considering its intracontinental disposition, the sedimentary evolution of the Mésogée depended upon tectonic movements. These movements, through their holding in check the shape and connections of the basins, led to the deposition of the great Neogene lithologic units which are true geological formations.

\section{REFERENCES}

Bell, W. C. et al., 1961. Geochronologic and chronostratigraphic units. Bull. Am. Assoc. Petrol. Geol. 45 (5), 666.

Bizon G., 1967. Contribution à la connaissance des foraminiféres planctoniques d'Epire et des iles Ioniennes. Technip ed. Paris.

,1966. Etude géologique de l'Epire et de la Grèce Nord-Orientale Technip ed. Paris.

Burollet P. F. and Dufaure Ph., 1972. The Neogene series drilled by the well MISTRAL No. 1 in the Gulf of Lion. In "Sedimentation in the Mediterranean Sea". D. J. Stanely (ed). Hafner Publishing Co. New York. 
Bourcart J., 1960-1962. La Méditerrannée et la révolution du Pliocène. Livre à la mémoire du Professeur P. Fallot. Société Géologique de France. 1, 103.

Durand Delga M., 1969. Mise au point sur la structure du Nord-Est de la Berberie. Publ. Serv. Geol. Algérie. (Nlle Série). No. 39, 89.

Gignoux M., 1913. Les formations marines pliocènes et quaternaires de l'Italie du Sud et de la Sicile. Thèse Sc. Lyon. Ann. Univ. Lyon. 1, 36.

, 1922. Le Pliocène et le Quaternaire marins dans la Méditerranée Occidentale. C. R. Congrès Géologique International. Bruxelles. Paris.

, 1950. Géologie Stratigraphique. Masson (ed).

Glangeaud L., 1962. Paléogéographie de la Méditerranée et de ses bordures. Le role des phases ponto-plioquaternaires. Océanogr. géologique et géogr. Médit. occ. Colloq. Centre Nat. Rech. Sc. 125.

Heybroek F., 1965 The Red Sea Miocene Evaporite Basin. In Salt Basins around Africa. 17. The Institute of Petroleum, London. Elsevier.

Ogniben L. Petrografia della serie Solfigera Siciliana e considerazioni geologiche relative. Mem. des Carta Geol. Italia. 33, 1.

Perrodon A., 1957. Etude géologique des bassins néogènes sublittoraux de l'Algérie occidentale. Publ. Serv. Carte Géol. alg. N. S. bull. 12.

Zenkovich V. P., 1966. Black Sea. In Encyclopedia of Oceanography. R. W. Fairbridge (Ed). Reinhold Pub. Co. New York. 